\title{
An Assessment of Local Empowerment and Environment Management Project (LEEMP) in Benue and Katsina States of Nigeria
}

\author{
Adam Adem Anyebe ${ }^{1} \&$ Victor Mkuma Bem ${ }^{2}$ \\ ${ }^{1}$ Department of Public Administration, Faculty of Administration, Ahmadu Bello University, Zaria, Nigeria \\ ${ }^{2}$ Registry Department, University of Agriculture, Makurdi, Nigeria \\ Correspondence: Adam Adem Anyebe, Department of Public Administration, Faculty of Administration, \\ Ahmadu Bello University, Zaria, Nigeria. E-mail: adamanyebe@gmail.com
}

Received: April 17, $2014 \quad$ Accepted: May 12, $2014 \quad$ Online Published: June 21, 2014
doi:10.5539/par.v3n2p1
URL: http://dx.doi.org/10.5539/par.v3n2p1

\begin{abstract}
It is generally claimed that in the past, poverty reduction programmes in Nigeria failed because the beneficiaries were not involved in the programme design and formulation. However, LEEMP was designed to be community driven and thus it was expected to record a level of success. This study, therefore, attempted to assess LEEMP in Benue and Katsina states. It was hypothesized among others, that LEEMP has reduced unemployment and poverty in Benue and Katsina states. The study used both primary and secondary data. The data obtained were presented in tabular form. T-test and cumulative percentages were adopted for analyzing and testing the hypotheses formulated. The study revealed among others, that LEEMP has not significantly reduced unemployment and poverty in the areas of study. In the same vein, the benefits of the LEEMP activities in the limited geographical coverage were subsumed by the general social infrastructural decay, hence no significant effect. It was suggested that LEEMP should be reviewed and expanded to ensure wider coverage.
\end{abstract}

Keywords: poverty, unemployment, empowerment, strategy, development, environment

\section{Introduction}

Poverty pervades in Nigerian society today. World Bank (1996) described Nigeria as a startling paradox given prevailing extent of poverty and statistics obtained in the country. Specifically, the country noted to be endowed with human, agricultural, petroleum, gas and large untapped solid mineral resources earned over US $\$ 300$ billion from petroleum in the last three decades of the twentieth century. Yet instead of recording remarkable progress in national socio-economic development, Nigeria retrogressed to become one of the 25 poorest countries at the threshold of twentieth century, whereas she was the $50^{\text {th }}$ richest in the early 1970s (Obadan, 2001). The National Poverty incidence also steadily increased over the period.

The initial national development plans in Nigeria indeed did not target empowerment/development via Poverty reduction. Thus, the main focus of the plans centered on ensuring rapid increase in the nation's productive capacity with a view to improving the living condition of the citizenry. Presumably therefore, the identifiable approaches to empowerment and development through poverty eradication featuring in the national development plans were the economic growth, which manifests in the trickling down of the benefits of growth to the poor. The second strategy is that of rural/agricultural development where efforts were made to enhance development of social and economic infrastructure.

According to Obadan (2001), formal empowerment and development strategies through conscious efforts at poverty eradication in Nigeria came to effect in 1994, when a poverty alleviation programme development committee (PAPDC) was inaugurated. By 1998, there were sixteen alleviation programmes or strategies set up specifically to address the continuous deterioration of living conditions. This laid the foundation on which poverty Eradication cum empowerment schemes emerged. Specifically, the National economic Empowerment Strategies (NEEDS) which formed the bedrock of LEEMP came up in 2004.

The evolution of LEEMP is as such anchored on the National Economic Empowerment Strategy (NEEDS). According to President Obasanjo (NEEDS, 2009: VI), the strategy is a response to the development challenges of Nigeria which most people had by 1999 grossly underestimated. The Obasanjo regime had on assumption of office therefore sought to mobilize the resources of Nigeria to make a fundamental break with the failures of the 
past. This was to enable the Federal Government bequeath a united and Prosperous nation to generations to come. NEEDS, is an institutional mechanism for achieving this onerous task required to achieve astute reorientation of values, poverty reduction, wealth creation and employment generation. It therefore, has a vision based on the Kuru Declaration of 2001. This embodied the vision of building a true great African democratic country, politically united, integrated and stable economically, prosperous, socially organized with equal opportunity for all. It was designed to become the catalyst of (African) Renaissance, making adequate and of all embracing contributions, sub-regionally, regionally and globally (NEEDS 2005: VIII).

The 36 States of the federation adopted NEEDS and further adapted it to suit their local needs. The States' version of this vision is known as State Economic Empowerment and Development Strategy (SEEDS). Nine states selected as pilot states: Adamawa, Bauchi, Bayelsa, Enugu, Imo, Oyo, Niger, Benue and Katsina launched their local Version of SEEDS in 2004 known as LEEMP. These states were selected on the basis of certain criteria which include:

$>$ That at least one State should be from each of the six geographical zones. Natural resources degradation wherein the populations are already experiencing or have begun to implement natural resource intervention.

> States should be willing to establish and fully fund salaries of at least 10 Fulltime Multidisciplinary Implementation Teams (MITS); each comprising full experienced government employees drawn from relevant State line ministries of Water Resources, Environment, Agriculture and Rural Development.

$>$ States should adopt an open transparent objective and competitive selection process for identifying members of the MITS.

States should already be implementing or have previous experience of implementing multi-sectoral projects involving cooperation across sectoral line ministries.

$>$ States that have already submitted proposals for multi-sectoral national resources management projects should be given priority.

$>$ States should be willing to adopt a community driven approach to integrated national resources management involving the decentralization of decision making responsibility and control and authority over-financial resources to beneficiary communities.

$>$ States should be willing to actively build capacity of LGAs.

$>$ States should be prepared to decentralize authority to LGAs for approving micro-project proposal emerging from beneficiary communities.

States with NGOS/CBO that has experience in facilitating community based natural resources management should be given priority.

$>$ States should be willing to allow NGOs/CBO's to act as independent MITS to complement the MITS comprising government employee.

States already identified for the World Bank supported community development programme should not be eligible for inclusion in the pilot phase of LEEMP, since that programme will also be targeting rural populations.

$>$ At least two of the states should have protected areas which have significant average and species, diversity and which do not currently have support from any donor agency or have pending proposals with GEF, to attract and absorb substantial GEF grant funding. Thus, Kainji and Yankari National parks met this requirement. (Benue LEEMP PIM 2004: 11).

States chosen in the pilot scheme which do not perform satisfactorily were to be replaced by the remaining states not originally selected.

LEEMP is Nigeria's plan for prosperity. It is the people's ways of letting government know what kind of Nigeria they wish to live in, now and in future, it is the government way of letting the people knows how they wish to overcome the deep and pervasive obstacles to progress that the government and people have identified. It is also a way of letting the international communities know where Nigeria stands in the region and in the world and how it wishes to be supported (Central Bank of Nigeria 2005)

The programme focuses on the four key strategies of reorienting values, reducing poverty, creating wealth and employment. Accordingly, its plan for prosperity aimed at addressing the startling paradox that more than two-third of the Nigeria people are poor in spite the country's vast potential wealth. The programme undertakes to effect change through empowering the people by ensuring that the people have access to adequate water and sanitation, nutrition, clothing shelter basic education and health care. It seeks to restore trust in government to 
create enabling environment that enables Nigeria supplement development strategies and achieve personal goals. New forces of coordinating and partnership between the private and public sectors are also to be provided.

LEEMP, as already stated, therefore draws heavily on provisions of SEEDS whose objectives and modus operandi are therefore similar to those of Benue and Katsina States' SEEDS. Generally, the programme developed as a result of the general prevailing situation in the country where the poverty incidence has been on the rise with Benue and Katsina states having their fair share of the ugly phenomenon. For instance the poverty incidence in Benue State of the extremely poor rose from $1 \%$ in 1980 to $25 \%$ in 1996 while the non-poor decreased from $77 \%$ in 1980 to $36 \%$ in 1996 thereby placing Benue State as the $8^{\text {th }}$ poorest state in the Federation as at 2004 (BENUE SEEDS, 2004:12).

To change the trend, the Benue LEEMP (BENLEEMP) introduced strategies to reduce poverty through improved income and consequently stimulate the desired growth and development in the state. The Katsina State LEEMP (KATLEEMP) has also introduced the same strategies. The central approach of this programme is designed to establish an institutional mechanism for transferring investment resources to communities in order to enable them to finance their own development priorities. It also emphasizes the sustainable management of the environment as a pre-requisite to sustainable livelihood and development (Benue LEEMP magazine 2008:5).

LEEMP activities are therefore geared towards sustained food security, employment opportunities, income generation in the agricultural sector, ensuring greater access to educational opportunities and skills acquisition to enhance production capacity. The environment aspect stresses that efforts are geared towards protecting the environment in order to promote socio-economic development of the present and future generations, provision of infrastructural base like rural roads, electricity to stimulate greater agricultural and industrial activities.

With these catalogues of intervening areas, LEEMP, particularly, in Benue and Katsina States has adopted the participant rural appraisal and the community driven approaches, where communities in conjunction with LEEMP officials select their priority projects in any of the intervening areas of agriculture, education, health, water resources, environment and finance etc. The Benue and Katsina LEEMP in this manner has since its existence provided school blocks, desks, and chairs, built culverts/constructed roads and bridges, built health centres, water shed management projects, constructed market stores, all worth hundreds of millions of naira across the two states (Benue LEEMP, 2008; Katsina LEEMP, 2009).

Therefore the adoption of community driven approach in promoting socio-economic development of the affected states, the Benue and Katsina LEEMP may have indirectly impacted positively on income advancement of the people. Thus, the poor in the states through the constructed projects in education may have become more literate and acquired better skills and could be gainfully employed. In the same vein, since it usually said that health is wealth, it means, that building of health centres through LEEMP activities would have indirectly empowered people. From adduced strategies of the LEEMP programme it can be deduced that policy objectives of the programme agree with the various ways outlined by the World Bank for improving the income of the poor. Thus as Okpe and Abu (2009) further note, the World Bank Report indicates that the Poor's income could be enhanced through:

$>$ Increase in demand for the labour of the poor

$>$ Increasing access of the poor to physical assets like land to raise their productivity.

$>$ Provision of social services such as education and health to the poor.

$>$ Transfer of current income to the poor inform of cash and subsidies.

\section{Statement of the Problem}

It is evident that poverty still pervades in the Nigerian society on a very large scale in spite of efforts for its eradication over the years. This means that the introduction of several poverty eradication and development stimulating programmes in Nigeria over the years could not achieve desired results.

Between Independence and 2004 a sizeable percentage of Nigeria's resources were increasingly invested in poverty alleviation and development strategies/programmes. Yet the poverty incidence has been on the rise. Federal office of Statistics (2002), Obadan (2009) confirmed that at least $25 \%$ of the undernourished populations in West Africa were Nigerians. Obadan further noted that there has been an increase in poverty incidence within and among locations in Nigeria. The North central geo-political zone covering Benue State experienced a poverty incidence of $32.2 \%$ in $1980,50.8 \%$ in 1985 and $64.63 \%$ in 1998 . Similarly, the North-West zone covering Katsina State experienced poverty incidence of $35.6 \%$ in $1980,54.9 \%$ in 1985 and $70.1 \%$ in 1998 (NEEDS 2005). Thus, in spite of the increased revenue and corresponding increased financial commitment to 
poverty eradication and development strategies, the Nigerian people have been falling deeper into poverty. In 1980, an estimated $27 \%$ of Nigerians lived in poverty, in 1990 about $70 \%$ of Nigerians had income of less than one dollar per day (NEEDS, 2005). Furthermore, the Human Development Index HDI (2009) observed that between $1990-2007$ Nigerian's HDI only rose by $0.915 \%$ annually from 0.438 to $0.511 \%$. This placed the country in position 102 of the 128 countries observed. Evidently, Nigeria like many developing countries has over the years experienced failures of poverty reduction and development programmes adopted wholesale without modification to suit the local need. Suffice to say that programmes like Family Economic Advancement Programme (FEAP), Family Support Programme (FSP) and several others introduced over the years by successive governments have not recorded any significant achievement.

In this regard, fundamental questions to be addressed include:

$>$ To what extent has LEEMP reduced income inequality and poverty in Benue and Katsina States?

$>$ To what extent has LEEMP provided social infrastructure or expanded the existing ones needed to stimulate economic and development oriented activities in Benue and Katsina States?

To what extent has LEEMP enhanced environmental management in Benue and Katsina States?

The main objective of this study, therefore, is to assess LEEMP in Benue and Katsina States. Specifically the study attempts to:

$>$ To assess the extent to which LEEMP has reduced unemployment and poverty in Benue and Katsina states.

$>$ To assess the extent to which LEEMP has provided social infrastructure or expanded the existing ones to stimulate economic and development oriented activities in Benue and Katsina states.

$>$ To assess the extent to which LEEMP has enhanced environmental management in Benue and Katsina states.

\section{Hypotheses}

This study is anchored on the following hypotheses:

$>$ LEEMP has reduced unemployment, and poverty in Benue and Katsina states.

$>$ LEEMP has provided social infrastructure and expanded the existing ones needed to stimulate economic and development oriented activities in Benue and Katsina states.

$>$ LEEMP has enhanced environmental management to create wealth in Benue and Katsina states.

\section{Literature Review}

In undertaking the review, some works on economic empowerment are examined. The work of Anyebe (2001) suffices. In his study of poverty and its management in Nigeria, he concluded that there was cyclical poverty in the area caused by lack of resources of production supported by insufficient availability of infrastructure. He observed that property defined world mean lack of sufficient ownership of active factors of production. He further stated that the management mission of poverty should be explained as empowering people with sufficient factors of production. He recommended also that people be empowered with sufficient land, labour, capital and enterprise, while government should provide for the technological and infrastructural base of the economy. The mission statement of LEEMP suggests that the communities would be economically empowered and developed by creating wealth and infrastructure out of the available resources. This would be done through community driven approach and efficient environmental management.

Another study conducted by Abdulahi (2008) on social policy and poverty alleviation in Gombe state (1996 2006), concluded that a lot needed to done to improve the living conditions and reduce poverty levels of the people. Also government's "so called concern", at best was explained to be mere political propaganda leading to pauperization of the majority and discontentment with government operations or programmes. He therefore recommended that urgent measures be taken to help ensure that there are basic and functional social services in the area of education, health services, and water supply and employment opportunities. Thus recommendations also based on statistical data from the research conducted have addressed issues of economic empowerment and development which LEEMP strives to achieve in the LEEMP communities. Again the suggestions would have achieved more success if specific recommendation were offered on how basic education, health facilities, portable water and other infrastructures could be provided. Consequently, the way forward is to adopt programmes that are actually formulated and designed to promote the interest of beneficiaries. This is against the back drop that most programmes as confirmed in previous studies failed because the beneficiaries were not involved in the programmes design. This led such programmes to focus on targets outside the interest of the 
beneficiaries. Again the implementers usually are far removed from the beneficiaries and the non - poor or target groups usually lose out. Other identifiable reasons accounting for unsuccessful attempts at empowerment in this environment has to do with the fact that the peculiarities of the Benue and Katsina society or the Nigeria environment are not usually considered when accepting wholesale prescriptions by the developed countries or their agents. To compound the issue, most often, loans collected from foreign agencies for developmental purposes are diverted for other uses (Kayode 2007:3). LEEMP which is designed to be community driven and to involve the beneficiaries in every aspect of its operation may be the required tonic.

\section{Method of Data Collection}

\subsection{Primary Sources}

The questionnaire, designed for this study was administered on the sampled population to elicit information from them. Some members of staff were interviewed to elicit information and data to substantiate or reconcile the information obtained through the questionnaire.

\subsection{Secondary Sources}

This involves the use of existing records, journals, newspapers/magazines, review of works of other scholars and also exploration of internet sources.

\subsection{Population and Sample Size}

LEEMP has organization and administrative structures at the state capitals of the nine participating states and also in the participating local government areas. In term of beneficiaries/participants, the LEEMP has its programmes in three (3) intervening local government areas in each of the three (3) senatorial zones of both Benue and Katsina states. There are a total of one hundred and six (106) LEEMP communities spread across the nine benefiting local government areas in Benue state, while Katsina State has ninety (90) communities, spread across the nine local government area in the three senatorial zones. Each of the participating LEEMP community is estimated to have a maximum number of three thousand (3000) people made up of the population of beneficiaries or participants in LEEMP activities.

Based on the foregoing and in line with the definition by Babie (1997) that population and universe are theoretically specified aggregation of survey elements. The population for this study was estimated to include all members of the LEEMP in Benue and Katsina states, as well as LEEMP staff in the studied states.

The estimated population was five hundred and eighty eight thousand, three hundred and six $(588,306)$ persons and this was grouped into four categories as the common characteristics permits: Benue LEEMP personnel/staff, Benue LEEMP participants/beneficiaries, Katsina LEEMP personnel/staff and Katsina LEEMP participants/beneficiaries. In view of the fact that the population as presented cannot be entirely observed, the selection of a smaller portion of the population usually referred to as a sample is inevitable.

\subsection{Stratified Random Sampling}

For the purpose of this study, stratified random technique was adopted because of the heterogeneous nature of the population. To determine the sample size that is considered adequate for this study, the method of mathematical computation which Udofia (2005: 171) and Asika N., (2001) recommend for choosing an appropriate sample size is adopted. This requires choosing a tolerable level of precision and for this study $5 \%$ level of tolerable error has been adopted for use in determining the sample size using the formula prescribed by Asika as presented below:

$$
\mathrm{n}=\mathrm{N} / 1_{-}(\mathrm{b})^{2}
$$

Where: $\mathrm{n}=$ sample size

$\mathrm{N}=$ population size

$\mathrm{B}=$ Limit of tolerable error

In applying the above formula, the population of LEEMP communities required to respond to the questionnaire was treated independent of the other elements in the population. Thus the population size of five hundred and eighty eight thousand $(588,000)$ was used to determine the sample size i.e.

$$
\mathrm{n}=\frac{588,000}{1+588,000(0.5) 2}
$$




$$
\begin{gathered}
\mathrm{n}=\frac{588,000}{1470.0025} \\
\mathrm{n}=399.99
\end{gathered}
$$

The sample size of 4000 respondents was therefore been adopted for this study. However, to ensure fair representation of views, the 400 respondents were distributed in relation to the population of LEEMP communities in each state. The table 1 captures the data.

Table 1. Composition of population and sampling sizes

\begin{tabular}{lccc}
\hline State & Pop figure & \%Composition & Sample figure \\
\hline BEN LEEMP & 31800 & $54 \%$ & 216 \\
KAT LEEMP Communities & 270000 & $46 \%$ & 184 \\
Total & 588000 & $100 \%$ & 400 \\
\hline
\end{tabular}

Sources: Survey by the researcher 2010

From table 1, 216 respondents were randomly selected from Benue, 184 respondents randomly, selected from Katsina. In addition, to above 20 staff were randomly selected from among the (306) staff in the two states to be interviewed.

\subsection{Questionnaires Administration and Interviews}

The instrument largely used for the collection of primary data for this study was the questionnaire, given that the questionnaire has the advantage of giving the respondents anonymity which creates room for correct assessment of issues. Thus, respondents who naturally would not respond would under cover of not facing an interviewer face to face would gladly fill the questionnaire; this increases the reliability of the results. The structured questionnaire technique was therefore adopted. The questions asked, sought answers from beneficiaries/participants in the programmes, on empowerment and development strategies in the Benue and Katsina LEEMP generally. In preparing these questions, therefore, care was taken to ensure that probing questions or private issues considered embarrassing were avoided, while making sure that the purpose and focus of the study was not lost. The questions were made simple enough for respondents to understand.

Closed ended questions were mainly adopted in this study, given their numerous advantages including the fact that they provide for uniformity of replies and ease of interpretation. A few open ended questions were also included to give respondents the opportunity to freely give information on the subject matter.

\subsection{Method of Data Presentation and Analysis}

The presentation of data and its analysis culminates in testing hypotheses. Therefore, the primary and secondary data collected with respect to the objectives of this study were analyzed using cumulative percentages and T-Test as well as simple linear regression.

T-Test: $\mathrm{Y}=\mathrm{a}+\mathrm{bx}$

Where $\mathrm{y}=$ dependent variable

$\mathrm{X}=$ independent variable

$\mathrm{a}=$ constant indicating the point of interception of $\mathrm{x}$ with the $\mathrm{y}$ axis.

$\mathrm{b}=$ parameter (the slope or gradient) that defines the specific relationship between $\mathrm{y}$ and $\mathrm{x}$.

$\mathrm{a}=\frac{\sum x^{2} \sum y-\sum x \sum x y}{N \sum x^{2}-\left(\sum x\right)^{2}}$

$\mathrm{b}=\frac{N \sum x y-\sum x \sum y}{N \sum x^{2}-\left(\sum x\right)^{2}}$

The $\mathrm{R} 2$ = show the percentage of the total variation in y explained by the regression plane (i.e. by the changes in $\mathrm{xi}$ and $\mathrm{x} 2$ ). The relevant formula is

$$
R^{2} y_{1} x_{1} x_{2}=\frac{b_{1} \sum y x_{1}+b_{2} \sum y x_{2}}{\sum y^{2}}(\text { multiple repression) }
$$




$$
\begin{gathered}
R^{2} y_{1} x_{1}=\frac{b_{1} \sum y x_{1}}{\sum y^{2}} \text { (simple repression) } \\
\text { The student's test tc }=\frac{b}{s\left(b_{i}\right)}
\end{gathered}
$$

The special package for social science (SPSS) was used in running the repression analysis, considering the fact that the package simplifies the procedure and produces results that are the same with those obtained though the manual method of calculating the $\mathrm{t}$ - test. In using the SPSS package these components are required:

\section{$>$ Level of significance}

$>$ The number of observation in the sample

$>\quad$ The number of parameter coefficients $(\mathrm{K})=\mathrm{I}$

$>\quad$ Degree of freedom (n-k)

For testing hypothesis I - III in this work, the values of the components are as follows;

level of significance $5 \%$

Number of observations in the sample $-(n)=5$

The number of parameter coefficients $(\mathrm{k})=1$

Degree of freedom $(\mathrm{n}-\mathrm{k})=4$

\subsection{Decision Rule}

The data obtained through the questionnaires are to be processed by sorting out the responses and matching them against their respective questions. These were presented in tabular form using simple percentages. Consequently the data were analyzed using the simple percentages. Interpretation of results was, therefore, based on variables with highest percentages.

For the T-Test the standard rules for decision making in a regression, when we accept the null hypothesis, we invariably reject the alternate hypothesis.

\subsection{Hypothesis I}

LEEMP has reduced unemployment, and poverty in Benue and Katsina states. The Cumulative Percentage Analysis was used to integrate responses on variables which relate to the test of Hypothesis one. In this wise, the percentage on relevant variables was used in the computations as detailed in table 2 . 
Table 2. Cumulative percentage analysis

\begin{tabular}{|c|c|c|c|c|c|c|}
\hline \multirow[t]{2}{*}{ Variable } & \multicolumn{6}{|c|}{ Responses } \\
\hline & $\begin{array}{l}\text { Very high } \\
\text { extent(VHE) }\end{array}$ & $\begin{array}{l}\text { High } \\
\text { extent(HE) }\end{array}$ & $\begin{array}{c}\text { Moderate } \\
\text { extent(ME) }\end{array}$ & $\begin{array}{l}\text { Low } \\
\text { extent(LE) }\end{array}$ & $\begin{array}{c}\text { Very low } \\
\text { extent (VLE) }\end{array}$ & \\
\hline $\begin{array}{l}\text { The appropriateness of LEEMP strategy as veritable } \\
\text { vehicle for development }\end{array}$ & 27.5 & 39.9 & 15.6 & 9.5 & 7.4 & \\
\hline $\begin{array}{l}\text { The extent to which LEEMP's CDP approach is } \\
\text { relevant in stimulating socio - economic activities } \\
\text { for accelerated development. }\end{array}$ & 32 & 49.2 & 13.5 & 3.7 & 1.58 & \\
\hline $\begin{array}{l}\text { The extent to which PRA facilitated the } \\
\text { identification and implementation of priority } \\
\text { projects for sustainable development }\end{array}$ & 50 & 38.8 & 8.99 & 1.06 & 1.06 & \\
\hline $\begin{array}{l}\text { The extent to which LEEMP impacted on members } \\
\text { of the society especially the vulnerable groups }\end{array}$ & 22 & 56.08 & 19.57 & 7.4 & 3.68 & \\
\hline $\begin{array}{l}\text { Self-assessment by respondents of perceived level } \\
\text { of income redistribution, improved employment } \\
\text { opportunities in LEEMP communities }\end{array}$ & 14.28 & 35.15 & 34.65 & 10.48 & 5.02 & \\
\hline Sub total & 145.78 & 219.13 & 92.31 & 32.14 & 18.76 & 508.12 \\
\hline Cumulative percentage & $\begin{array}{l}145.7 \div 508 x \\
100=28.69\end{array}$ & $\begin{array}{l}219.13 \div 508 \\
\times 100=43.13\end{array}$ & $\begin{array}{l}92.31 \div 508 \times \\
100=18.17\end{array}$ & $\begin{array}{l}32.14 \div 508 x \\
100=6.32\end{array}$ & $\begin{array}{l}18.76 \div 508 x \\
100=3.69\end{array}$ & $100 \%$ \\
\hline
\end{tabular}

Source: Field Survey 2010

From the analysis in table 2, it is reasonable to state that LEEMP actually restored economic independence and confidence of beneficiaries which ought to have facilitated reduction in unemployment, income inequality and poverty generally. The analysis shows that very high extent has $28.69 \%$, high extent has $43.13 \%$, moderate extent $18.17 \%$, the low extent $6.32 \%$ and very low extent, $3.19 \%$. Thus the majority (43.13\%) of the respondents accepted that LEEMP empowered the beneficiaries thereby making them independent and confident to embark on socio - economic activities that would improve their living conditions.

\subsection{Analysis of Hypothesis I Using Regression T-Test to Measure/Analyze Secondary Data}

The regression technique is used here to test quantitative data on micro projects executed across the intervention sectors to reduce unemployment income inequality and poverty generally in the benefiting communities. The aim therefore, is to establish the relationship between projects executed across the sectors and increased output/income generation, greater employment and poverty reduction among the communities accessing the facilities.

Table 3. Funds disbursement and the number of people accessing the facilities provided by LEEMP in Benue State

\begin{tabular}{cccc}
\hline Year & \multicolumn{2}{c}{ Amount disbursed } & Population accessing the facilities \\
\hline 2004 & $\mathrm{~N}$ & $\$$ & 19,557 \\
2005 & $15,481,761.1$ & $140,326.62$ & 92,896 \\
2006 & $73,538,365.2$ & $666,095.98$ & 287,652 \\
2007 & $227,710,903.35$ & $2,063,811.74$ & 322,027 \\
2008 & $278,671,000$ & $2,528,454.02$ & 621,746 \\
& $49,670,650.2$ & $450,886.45$ & 814,877 \\
\hline
\end{tabular}

Source: LEEMP Evaluation Report (2010) 
Table 4. Showing funds disbursement and the population accessing the facilities provided by LEEMP in Katsina State

\begin{tabular}{cccc}
\hline Year & Amount disbursed & \multicolumn{2}{c}{$\begin{array}{c}\text { Population accessing the } \\
\text { facilities }\end{array}$} \\
\hline 2004 & $8,122,463.85$ & $83,409.12$ & 13,185 \\
2005 & $56,857,246.9$ & $578,735.32$ & $83,409.12$ \\
2006 & $174,362,221$ & $1,776,266.22$ & $578,735.32$ \\
2007 & $249,088,891$ & $2,546,819.37$ & $1,776,266.22$ \\
2008 & $53,066,763.8$ & $539,908.50$ & $2,546,819.37$ \\
Total & $541,497,590$ & $5,525,138.53$ & $539,908.50$ \\
\hline
\end{tabular}

Source: LEEMP Evaluation Report (2010)

\subsection{Presentation of Results}

The data as already stated in tables 3 and 4 were inputted into the SPSS and processed accordingly. The results produced are presented in table 5

Table 5. Computation

\begin{tabular}{lll}
\hline & Benue & Katsina \\
\hline Estimated regression equation & PAF $=4958.699+0.44 .0 \mathrm{AD}$ & $\mathrm{PAF}=222.200+0.313 \mathrm{AD}$ \\
Student test $(\mathrm{Tc})$ & 19.260 & 365,839 \\
Standard error & 11257.326 & 687,222 \\
Coefficient of multiple determination $\left(\mathrm{R}^{2}\right)$ & 0.995 & 1.000 \\
\hline
\end{tabular}

\subsection{Interpretation of Results}

The equation above $\mathrm{PAF}=4958.539+0.440 \mathrm{AD}$ and $\mathrm{PAF}=222.200+0.323 \mathrm{AD}$ explains the estimated regression for Benue and Katsina states respectively. The implication of the functions is that an increase in funds disbursed by LEEMP in each state by $1.00 \%$ led to an increase to 0.440 and $0.323 \%$ increase in the population accessing the facilities provided in Benue and Katsina States respectively. This further means that funds disbursed to provide facilities in LEEMP communities improved and expectedly with more people accessing them; thereby attempting to reduce unemployment, income inequality and poverty generally. The coefficient of multiple determinants $\left(\mathrm{R}^{2}\right)$ shows that $99.5 \%$ and $100 \%$ variations in the population accessing the facilities provided by LEEMP in Benue and Katsina States respectively is due to variations in funds disbursed.

The students test (tc) values of 19.260 and 365.83 for Benue and Katsina States respectively also confirm that the funds disbursed had a positive significant impact on the population accessing the facilities, thereby achieving significant improvement in people's income and generally reducing poverty.

This positive and significant impact of funds disbursed by LEEMP on the population is further confirmed by the standard errors of 11257.326 and 689.272 .

\subsection{Hypothesis II}

LEEMP has provided social infrastructure and expanded the existing ones needed to stimulate economic and development oriented activities in Benue and Katsina states. The analysis of the cumulative percentages seeks to integrate results of variables which relate to the test of hypothesis II. This is done by way of computation as detailed in table 6 
Table 6. Cumulative percentage analysis

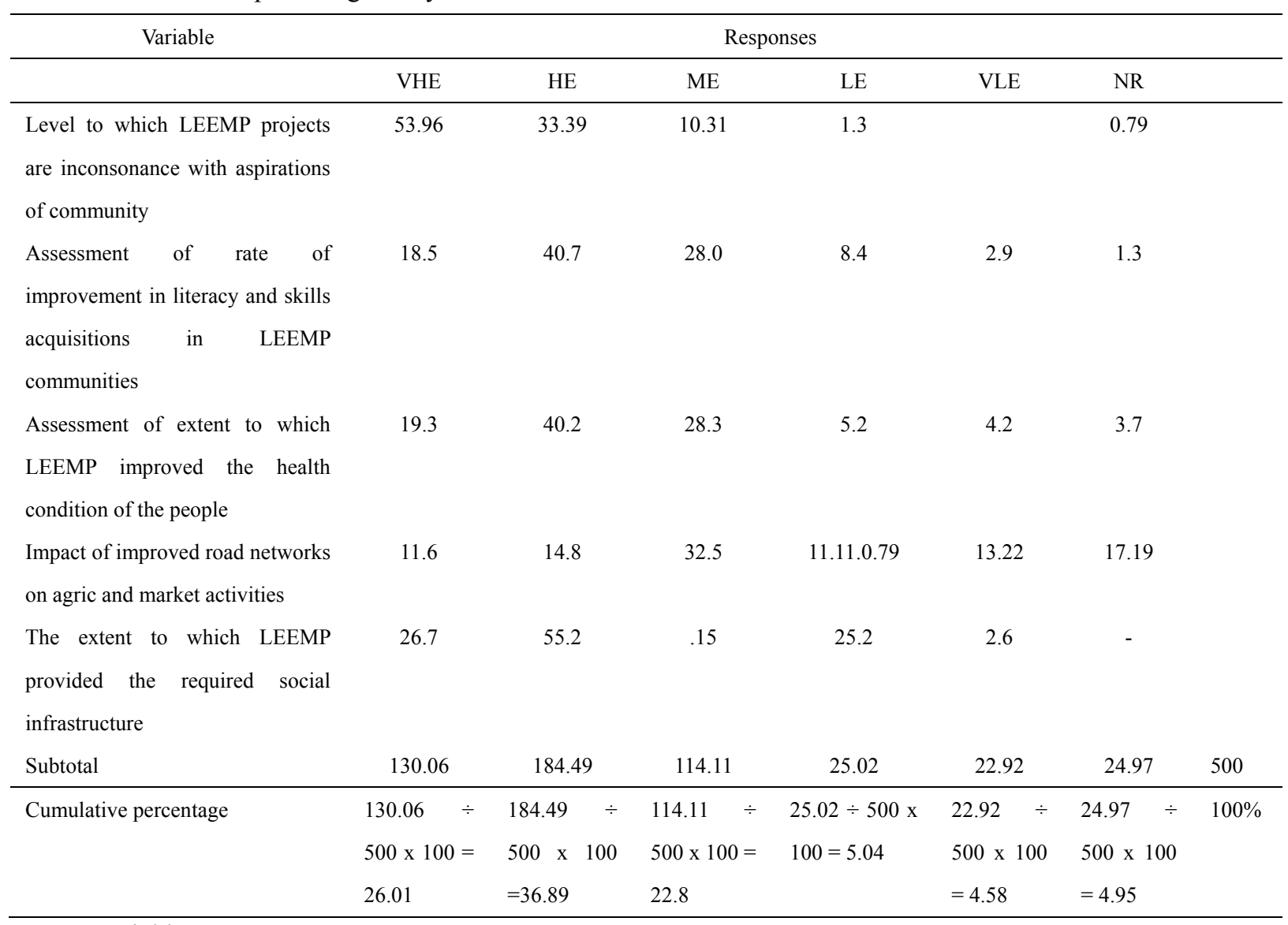

Source: Field Survey 2010

The computations in the above table present opinions of respondents regarding the variables that tested hypothesis II, which culminates to cumulative percentage analysis. The very high extent has $26.01 \%$, high extent has $36.89 \%$, and moderate extent has $22.8 \%$ low extent $5.04 \%$ very low extent $4.58 \%$ while respondents who had no response accounted for $4.95 \%$. This attests to the fact that LEEMP to a high extent achieved targets by undertaking projects in sectors such as health, water, education, environment etc. which all combined to provide the infrastructure necessary stimulate socio - economic activities thereby empowering the people for sustainable development.

However this is not to conclude that LEEMP has achieved total success in empowering people for sustainable development given that a good number of persons in the intervention areas still live below poverty level and also are not totally literate nor are fully mobilized to undertake socio-economic activities that would translate to development. But this is to be expected considering that the respondents themselves have already indicated that LEEMP has not totally achieved the envisaged results or provided the required infrastructure to a very high extent. Thus, the rural areas particularly where LEEMP projects were executed experienced quantitative increase in literacy levels, health institutions, roads and market expansions culminating in boosting economic activities without actually uplifting the standard of living of the people as desired.

\subsection{Analysis of Hypothesis II Using Regression (T) Test to Measure/Analyze Secondary Data}

The regression analysis technique has been used to test this hypothesis using secondary (quantitative) data. This is aimed at establishing the impact or relationship the funds disbursed by both the Benue and Katsina LEEMP have on the provision of micro projects. This in view of the expectation that funds disbursed would have a direct impact on the provision of social infrastructure needed to stimulate economic and development oriented activities. The test should help establish this relationship. 
Table 7. Funds disbursement and the micro projects executed across the sectors in Benue State

\begin{tabular}{cccc}
\hline Year & \multicolumn{2}{c}{ Amount disbursed } & Micro Projects Executed \\
\hline & $\mathrm{N}$ & $\$$ & \\
2004 & $15,481,761.1$ & $140,326.62$ & 15 \\
2005 & $73,538,365.2$ & $666,095.98$ & 69 \\
2006 & $227,710,903.35$ & $2,063,811.74$ & 215 \\
2007 & $278,671,000$ & $2,528,454.02$ & 263 \\
2008 & $49,670,650.2$ & $450,886.45$ & 47 \\
Total & $645,073,379.35$ & $5,849,594$ & 609 \\
\hline
\end{tabular}

Source: Statistics from project impact evaluation of LEEMP 2010

Table 8. Funds disbursement and the micro projects executed across the sectors in Katsina State

\begin{tabular}{cccc}
\hline Year & & Amount disbursed & Micro Projects Executed \\
\hline & $\mathrm{N}$ & $\$$ & \\
2004 & $8,122,463.85$ & $83,409.12$ & 2 \\
2005 & $56,857,246.9$ & $578,735.32$ & 41 \\
2006 & $174,362,221$ & $1,776,266.22$ & 121 \\
2007 & $249,088,891$ & $2,546,819.37$ & 173 \\
2008 & $53,066,763.8$ & $539,908.50$ & 38 \\
Total & $541,497,590$ & $5,525,138.53$ & 375 \\
\hline
\end{tabular}

Source: Statistics from project impact evaluation of LEEMP 2010

Table 9. Presentation of results

\begin{tabular}{lll}
\hline & Benue & Katsina \\
\hline Estimated regression equation & MPE $=0.065+0.192 \mathrm{AD}$ & MPE $=7.0322+0.820 \mathrm{AD}$ \\
Student test (ti) - & 511.522 & 55,418 \\
standard error $(\mathrm{s})$ & 0.339 & 1,963 \\
Coefficient of multiple determination $\left(\mathrm{R}^{2}\right)$ & 1,000 & 0.999 \\
\hline
\end{tabular}

\subsection{Interpretation of Results}

The results (equation) for the two states show the regression function or relationship between funds disbursed and provision of social infrastructure needed to stimulate economic development. The equation implies that an increase in funds disbursement by 1.00 led directly to $90.192 \%$ increase in the provision of infrastructure development projects which in turn stimulated economic development in Benue State. In Katsina State, the results indicate that a $1.00 \%$ increase in funds disbursement by LEEMP led directly to a $0.820 \%$ increase in the provision of development infrastructures, which in turn stimulated economic development in Katsina State.

It can also be concluded from the equation for the two states that funds disbursement has a positive relationship with micro projects provided, implying that LEEMP has provided social infrastructure and expanded existing once to stimulate economic and development oriented activities in the two states. It is also a confirmation that an increase in funds disbursement led to increases in provision and expansion of infrastructure.

At another level, R - square of the estimated regression equation is 1.000 and 0.999 for Benue and Katsina States respectively. This means that about $100 \%$ and $99.9 \%$ of the variations seen in the provision of micro project for both Benue and Katsina States are due to the predictor variables considered.

The ANOVA statistics displayed is also a confirmation of the adequacy of the regression equation. In the analysis the $\mathrm{P}$ - values for both states is 0.000 and 0.000 respectively and are therefore accepted as been adequate since, $\mathrm{P}$ - values of ANOVA test less than 0.05 at $5 \%$ level of significance is usually considered adequate. The 
coefficients of funds disbursed are positive and significant for both states as shown by the students test; tc $=$ 511.522 for Benue and tc $=55.418$ for Katsina State, implying that funds disbursed have significant positive impact on the provision of micro projects in the studied states. The standard errors of $34 \%$ and $19.6 \%$ also imply a significant positive impact of the independent variables (funds disbursed). The students test (tc) was used in computing coefficients for funds disbursement with $n-$ I degree of freedom of $5 \%$ level of significance in the test.

\subsection{Hypothesis III}

LEEMP has enhanced environmental management to create wealth in Benue and Katsina states. The analysis of cumulative percentages is designed to integrate result of variables and their responses which relate to the test of hypothesis III. Thus percentages of responses on relevant variables are presented in table 10.

Table 10. Cumulative percentage analysis

\begin{tabular}{|c|c|c|c|c|c|c|c|c|}
\hline Variable & & & & Responses & & & & \\
\hline & VHE & $\mathrm{HE}$ & ME & LE & VLE & \multicolumn{2}{|c|}{ NR } & \\
\hline $\begin{array}{l}\text { Assessment of the extent to which LEEMP } \\
\text { enhances sustainable management of the } \\
\text { environment }\end{array}$ & 22.5 & 58 & 15.3 & $2.38 \%$ & 1.85 & \multicolumn{2}{|l|}{-} & \\
\hline $\begin{array}{l}\text { Respondent assessment of the Level to which } \\
\text { LEEMP enhances maintenance of } \\
\text { environmentally sustainable projects }\end{array}$ & 27.2 & 58.6 & 12.4 & 2.1 & 1.05 & \multicolumn{2}{|l|}{ - } & \\
\hline $\begin{array}{l}\text { Impact Assessment of benefits of } \\
\text { environmental protection offered by LEEMP }\end{array}$ & 26.65 & 50.26 & 18.5 & 3.2 & 1.58 & & & \\
\hline $\begin{array}{l}\text { Assessment of LEEMP's GEF for improving } \\
\text { the utility of natural/environmental resources }\end{array}$ & 8.7 & 30.6 & 24.5 & 6.34 & 1.6 & \multicolumn{2}{|c|}{28.6} & \\
\hline $\begin{array}{l}\text { Extent to which LEEMP created wealth } \\
\text { through intervention in environmental/ natural } \\
\text { resources }\end{array}$ & 19.84 & 35.18 & 21.6 & 14.2 & 9.5 & \multicolumn{2}{|l|}{ - } & \\
\hline Sub total & 104.69 & 232.04 & 92.3 & 28.04 & 15.58 & \multicolumn{2}{|c|}{28.6} & 500 \\
\hline \multirow[t]{4}{*}{ Cumulative percentage } & $104.69 \div$ & $232.04 \div$ & $92.3 \div 500$ & $28.04 \div$ & $15.58 \div$ & 28.6 & $\div$ & 100 \\
\hline & $500 \times 100=$ & $500 \times 100=$ & $\mathrm{x} 100=$ & $500 \times 100$ & $500 \times 100$ & 500 & $\mathrm{x}$ & \\
\hline & 20.64 & 46.52 & 18.46 & $=5.6$ & $=3.16$ & 100 & $=$ & \\
\hline & & & & & & 5.72 & & \\
\hline
\end{tabular}

Source: Field Survey, 2010

From the computation culminating from the cumulative percentage analysis of variables regarding opinions of respondents, the hypothesis III has in this manner been tested. Thus, very high extent (VHE) has $20.64 \%$, high extent (HE) has 46.52\%, moderate extent (ME) 18.46\%, low extent (LE) 5.6\%, very low extent (VLE) $3.16 \%$ and no result (NR) $5.72 \%$. This means that the LEEMP reasonably created wealth through natural resources utilization for sustainable development. Thus majority of the respondents $(46.52 \%)$ adjudged the programme to have achieved this feat to a high extent.

In essence, LEEMP as a programme may have achieved a good measure of success in actualizing the pre-set objective of wealth creation through natural resources utilization.

\subsection{Analysis for Hypothesis III using Regression T- Test to Measure/Analyze Secondary Data}

The regression technique is used here to test quantitative data on efficient utilization of natural resources leading to wealth creation. The aim is to establish the relationship of the projects executed in environment and natural resources sector with wealth creation measured in terms of amount disbursed and number of projects executed in the environment and natural resources sector. 
Table 11. Funds disbursement and micro project executed in environment and natural resources sector in Benue State.

\begin{tabular}{|c|c|c|}
\hline Year & Amount disbursed & Micro project executed \\
\hline 2004 & - & - \\
\hline 2005 & - & - \\
\hline 2006 & 120,000 & 1 \\
\hline 2007 & 270,000 & 2 \\
\hline 2008 & - & - \\
\hline Total & 390.000 & 3 \\
\hline
\end{tabular}

Source: Statistics from project impact evaluation of LEEMP (2010)

Table 12. Funds disbursement and micro project executed in environment and natural resources sector in Katsina State

\begin{tabular}{ccc}
\hline Year & Amount disbursed & Micro project executed \\
\hline 2004 & 530,741 & 1 \\
2005 & $2,919,076.1$ & 7 \\
2006 & $8,544,931.7$ & 19 \\
2007 & $12,207,045.3$ & 28 \\
2008 & $2,653,705.5$ & 6 \\
Total & $26,537,055.02$ & 61 \\
\hline
\end{tabular}

Source: Statistics from project impact evaluation of LEEMP (2010)

Table 13. Presentation of results

\begin{tabular}{lll}
\hline & Benue & Katsina \\
\hline Estimated regression equation & PAF $-023+-508 \mathrm{AD}$ & PAF $-23131-589 \mathrm{AD}$ \\
Student test $(\mathrm{Tc})$ & $.4936 \mathrm{E} 4$ & .589 \\
Standard error & 45 & 39258 \\
Coefficient of multiple determination $\left(\mathrm{R}^{2}\right)$ & 1.000 & $1.000^{\mathrm{a}}$ \\
\hline
\end{tabular}

\subsection{Interpretation of Results}

The above results (equation) for the two states show the regression function or relationship between funds disbursed and provision of social infrastructure needed to stimulate economic development. The equation implies that an increase in funds disbursement by 1.00 led directly to $90.192 \%$ increase in the provision of infrastructure development projects which in turn stimulated economic development in Benue State. In Katsina State, the results indicate that a $1.00 \%$ increase in funds disbursement by LEEMP led directly to a $0.820 \%$ increase in the provision of development infrastructures, which in turn stimulated economic development in Katsina State.

It can also be concluded from the equation for the two states that funds disbursement has a positive relationship with micro projects provided, implying that LEEMP has provided social infrastructure and expanded existing once to stimulate economic and development oriented activities in the two states. It is also a confirmation that increase in funds disbursement will lead to increases in provision and expansion of infrastructure.

At another level, $\mathrm{R}$ - square of the estimated regression equation is 1.000 and 0.999 for Benue and Katsina States respectively. This means that about $100 \%$ and $99.9 \%$ of the variations seen in the provision of micro project for both Benue and Katsina States are due to the predictor variables considered.

The ANOVA statistics displayed is also a confirmation of the adequacy of the regression equation. In the analysis the $\mathrm{P}$ - values for both states is 0.000 and 0.000 respectively and are therefore accepted as been adequate since, $\mathrm{P}$ 
- values of ANOVA test less than 0.05 at $5 \%$ level of significance are usually considered adequate. The coefficients of funds disbursed are positive and significant for both states as shown by the students test; tc = 511.522 for Benue a tc $=55.418$ for Katsina State, implying that funds disbursed have significant positive effect on the provision of micro projects in the studied states. The standard errors of $34 \%$ and $19.6 \%$ also imply a significant Comparative Analysis of LEEMP in Benue and Katsina States

The LEEMP as a programme has a national outlook, the objectives, structure and functions and or operations are supposed to be similar in all states participating in the scheme. Yet some obvious variations arose due mainly to administrative, geographical, environmental and cultural differences.

For instance, in Katsina state, each of the (9) nine local governments in the (3) three senatorial districts have 10 CDPs which add up to 90 CDPS in the state. In Benue state it is on record that within the (9) nine local governments across the three (3) senatorial districts, there are 106 CDPs. An interview of staff of LEEMP on the possibility for this disparity did not yield plausible explanations.

There also exist variations in application of funds to different sectors in the two states. The Benue LEEMP committed the sum of six hundred and forty five million, seventy three thousand, three hundred and seventy nine naira, thirty five kobo (N645, 073,379.35) in executing a total of 609 projects in the LEEMP communities with the education sector having the largest number of projects (220) and therefore also consuming the largest percentage of the amount spent on various sectors. In Katsina State the LEEMP spent five hundred and forty one million, four hundred and ninety seven thousand, five hundred and ninety naira, twenty four kobo (N541, 497,590.24) on 374 projects, with the education sector with 77 projects taking the largest share of money spent. Benue LEEMP therefore spent one hundred and three million, five hundred and seventy five thousand, seven hundred and eighty nine naira, eleven kobo $(\mathrm{N} 103,575,789.11)$ more than the Katsina LEEMP. However on the average Benue LEEMP spent one million, fifty nine thousand, two hundred and thirty three naira, seventy nine kobo $(\mathrm{N} 1,059,233.79)$ per project, while Katsina LEEMP spent one million four hundred and forty seven thousand, eight hundred and fifty, four naira, fifty two kobo (N1,447,854.52) per project.. However the nature of projects in each sector determines the amount of funds needed for their execution, whereby smaller number of projects in certain sectors attracts larger sums of money. In this wise Benue LEEMP communities had electrical projects as their least priority while the Katsina LEEMP community had socio economic sector as their least priority.

Variations also exists in personal attributes and views of respondents in the two states The analysis of personal attributes of respondents show that a larger percentage of women participated in the scheme in Benue State as compared to the women participation in Katsina. Here again it was found that the socio - cultural environment played a major role as women in Benue State are by tradition more involved in outdoor activities. Similarly it was found that a higher percentage of the youths participated in the programme in Benue State than in Katsina State.

In line with the forgoing higher percentage of respondents from Katsina State confirmed that their living conditions were improved to a high extent by LEEMP while the highest percentage of Benue State respondents confirmed that their living conditions were only improved moderately. In the same vein a higher percentage of Benue respondents confirmed that LEEMP did not maximize the strategy of utilization of natural resource for wealth creation, while a greater percentage of Katsina respondents confirmed that the strategy was maximally explored. Also a higher percentage of Katsina State respondents confirmed that LEEMP as a strategy was to a very high extent an appropriate veritable vehicle for poverty reduction, while a greater percentage of Benue State respondents agreed it was an appropriate strategy for poverty reduction only to a high extent. The Katsina State respondents by percentage also confirmed that LEEMP PRA facilitated the identification and implementation of priority projects in the LEEMP communities to a very high extent, while a greater percentage of respondents in Benue State agreed it did only to a high extent. A greater percentage of respondents in Katsina agreed that they were actually deprived, powerless and vulnerable to a very high extent prior to the introduction of LEEMP. On the other hand the Benue State respondents agreed they were powerless, vulnerable and deprived only to a high extent. The greater percentage of Katsina State respondents also agreed that LEEMP empowered them to a very high extent, while the Benue participants said they were only empowered to a high extent. A higher percentage of Benue respondents also agreed that the LEEMP projects improved their output moderately, while a greater percentage of Katsina State respondents agreed that their output increased to a high extent. This also translated in a similar manner in reduction of unemployment and poverty in the two states.

\subsection{Analysis of Data Obtained from Interview with LEEMP Staff}

The interviewees generally agreed that the programme adopted strategies that could successfully transfer 
investment resources to beneficiaries and consequently reduce poverty in society, for sustainable development to be achieved. The PRA which allowed communities prioritize their development needs for execution through counterpart funding enhanced community driven development emphasized by the LEEMP.

\subsection{Interviews on How Staff Selection Impacted on the Performance of LEEMP}

The general opinion of the interviewees in the studied states was that the high quality staff were selected and or seconded to LEEMP. All organs of the institutional machine at all levels of government had trained professionals and specialists to undertake assigned tasks. On the whole the general assessment of the interviewees was also that the quality staff selected for the programme provided quality services leading to improvement in living condition of beneficiaries.

\subsection{Interviewees Comments on the Strategy for Managing the Environment adopted by the LEEMP}

The LEEMP emphasizes the affective management of environment to enhance full utilization of environmental resources to create wealth for sustainable development. Staff of LEEMP in this regard, were requested to assess LEEMP in terms of having in place a mechanism for ensuring effective management of the environment.

The interviewees confirmed that environmental Laws and other relevant Acts required were not promulgated at the close of the programme. These were meant to ensure the protection and efficient management of the environment to enhance full utilization of natural resources. However the interviewees confirmed that there were relevant trainings on environmental management as well as creation of awareness on environmental management at all levels. It was further confirmed that benefitting communities were trained on environmental conservation. In the final analysis, it is established that environmental protection and management which should be a top priority of this programme was given attention only to a minimal level. Definitely there would be limitation in full utilization of environmental resources.

\section{Major Findings}

$>$ The analysis show that LEEMP to some extent restored economic independence and confidence of beneficiaries. $43.13 \%$ of the respondents attested that they were empowered to a high extent. However $18.17 \%$ of the respondents said they were empowered to a moderate extent, $6.32 \%$ said they were empowered to a low extent, and only $3.69 \%$ to a very low extent. This shows that total success was not achieved

$>$ The research also revealed that increased fund disbursement led to increased infrastructural provision. The respondents confirm that the LEEMP to a high extent provided the required infrastructure necessary to stimulate the socio economic activities required to enhance sustainable. However complete success was not achieved.

$>$ The results confirmed that improved funds disbursement led to improved increase in utilization of environment and natural resources utilization leading to wealth creation, and empowerment for sustainable development. In essence LEEMP achieved some measure of success in utilization of natural resources leading to wealth creation.

\section{Recommendations}

Pertinent recommendations are made based on the findings of the study and they are as follows:

$>$ The proposed legislations to protect and efficiently manage the environment should be put in place to ensure that environmental resources are maximally utilized for the benefit of members of the society. Efforts should also be made to expand existing bio diversity/protected areas as well providing more of such areas as they have the advantage of not only generating funds but also providing more employment, and ensure that Nigerians have access to the nation's resources.

$>$ Thus, government should educate and mobilize the masses to jointly increase their capacity for dealing with the environment for improved capacity and output, such that there will be positive changes in the wellbeing of the individual. Government will encourage achievement of this feat through; diversification of economic activities from mono-cultural economic activities. This will reduce stress on rural environment and increase earnings for the rural dwellers usually targeted for accelerated development. Relatedly, if producers and consumers are educated on the cost of using the natural resources and the cost transferred to production cost, the stress on the environment shall be reduced for efficient usage of environmental resources.

$>$ LEEMP as a programme should be re-examined and possibly expanded to ensure that greater population is covered. Relatedly, the increased funding shall ensure wider geographical coverage. This will at least increase the number of beneficiaries and or participants and to some extent diffuse the poverty level in the larger society. Government should also make attempt to improve the social sector as continued societal decay places much stress on the on the developmental efforts of the LEEMP. 
$>$ A major improvement in support for the social sector is necessary to ensure that poverty eradication efforts of LEEMP and similar programmes are sustained. Thus complementary improvement in the social condition through government social responsibility is necessary if the poverty reductions cum empowerment strategies in LEEMP are to be effective. In other words government should ensure that workers in both private and public sectors are placed on a living wage, which affords them the basic necessities of life. This alone will reduce the dependence of the urban white/Blue Collar workers on the rural areas for living supplements and consequently reduce the stress on rural resources thereby enhancing increased earnings.

$>$ Related to above, in redesigning the programme, activities to encourage economic growth and development should be emphasized. Thus rural electrification if undertaken on larger scale will encourage primary industries, which will in turn service the processing of secondary industries culminating to employment generation and consequent qualitative and quantitative reduction in poverty for sustainable development to be achieved. Also as respondents suggested greater skills acquisition will improve productive capacity of the masses.

$>\quad$ The personnel working to ensure success of LEEMP should be further trained. Again experienced professionals and specialists if engaged may be able to identify shortcomings of adopted strategies. This will go further in ensuring that the LEEMP objectives of embarking on projects to reduce unemployment, improve living conditions and cause sustainable development in society are more efficiently achieved.

$>$ Cultural, environmental, geophysical variations of different parts of the country should be taking into consideration when empowerment and development programmes are packaged to avoid wholesale implementation across board. This will ensure equal satisfaction of interests of all members of society.

\section{References}

Abdulahi M. I. (2008) Social policy and poverty Alleviation in Gombe (1996-2006). Unpublished PhD Dissertation presented in Department of Public Administration Ahmadu Bello University Zaria.

Asika N. (2001). Research Methodology in the Behavioral Science (4th ed.). Longman Nigeria.

Babie, E. R. (1997). Survey Research Methods. Wadsworth California.

BENSEEDS. (2004). Benue State Economic Empowerment and Development Strategy. Second Draft Strategy Report.

Benue LEEMP. (2008). Achieving Rapid Rural Community Development Super Graph Printers, Makurdi.

Benue State. (2009). SCDA Project Manual. Government Printer Makurdi.

Central Bank. (2005). National Economic Empowerment and Development Strategy NEEDS.

Fed Office of Statistics. (2002). Poverty in Nigeria an Over view of the underlying cases. Abuja Nigeria.

Federal Government of Nigeria: NEEDS, 2005.

Federal Government of Nigeria: NEEDS, 2007.

Federal Government of Nigeria: NEEDS, 2009.

Katsina LEEMP. (2009). Summary of Micro Projects Status as at June $26^{\text {th }} 2009$.

Kayode, A. (2007). Poverty Alleviation in Nigeria: A Challenge for the Public Service. A PhD Seminar Paper presented at ABU Zaria.

Obadan, M. I. (2001). Poverty Reduction in Nigeria. The Way Forward. CBN Economic and Financial Review, $39(4)$.

Okpe, L. S., \& Abu, G. A. (2009). Foreign Private Investment and Property Reduction in Nigeria (1975 to 2003 ). Journal of Social Science, 19(3).

Udofia, E. P. (2005). Fundamentals of Social Science Statistics. Immaculate, Publications Ltd. Nigeria.

World Bank. (1996). Nigeria Poverty in the Midst of Plenty. The Challenge of Growth with Inclusion. Washington D.C. World Bank.

\section{Copyrights}

Copyright for this article is retained by the author(s), with first publication rights granted to the journal.

This is an open-access article distributed under the terms and conditions of the Creative Commons Attribution license (http://creativecommons.org/licenses/by/3.0/). 